\title{
Airbnb: Managing trust and safety on a platform business
}

Teaching article

\author{
Caoimhe Walsh, Deepak Saxena* and Laurent Muzellec \\ Trinity Business School, Trinity College Dublin
}

\begin{abstract}
AirBnB has become a preferred accommodation marketplace for the travellers around the world. AirBnB is a two-sided digital platform that connects guests and hosts. In so doing, it creates value for both sides of the platform. Guests save money on the accommodation and hosts get earnings from their otherwise idle space. The case follows the company from the inception to its growth and current challenges with wider community. The case helps to understand the key features of digital platforms: how do they create value for all users; how do they shape value propositions for two sides, and how does the community become a stakeholder in the platform business. It also focuses on the issue of trust and the need for the company to integrate the concerns of other stakeholders such as communities and local authorities. Finally, the case highlights the impact of Covid-19 on the company and the travel industry.
\end{abstract}

Keywords: digital platform, multi-sided platform, value proposition, business model, trust

(c) Sciendo

\section{INTRODUCTION}

AirBnB is a digital accommodation marketplace providing access to 7 million places to stay in more than 100,000 cities and 220 countries/regions around the world ${ }^{1}$. It does this by connecting the owners of accommodation (referred to as hosts) with customers (guests) who would like to use this accommodation on their travels. The company had been experiencing exponential growth since its inception in 2007. However, in recent years it has started to experience some difficulties. For example, during the autumn of 2017, five people died due to a shooting incident during a Halloween party in Orinda, California. The property was rented using the AirBnB platform. This reflects a growing discontent of the community in AirBnB hotspots. There have been lawsuits on the company in France, its biggest market outside US. In Ireland, AirBnB is blamed for a reduction in the supplies of long terms rentals in Dublin, and thereby fuelling the housing crisis. Such incidents started to put a question mark on the trust ecosystem that company has built over the years. Yet, these criticisms were small waves in comparison to the tempest that was coming next. During the spring of 2020, the covid-19 pandemic took the world by surprised. In order to slow down the spread of the virus, governments all across the world imposed travel restrictions. This practically annihilated all AirBnB revenue until the beginning of summer 2020. In the words of AirBnB CEO, the pandemic presents 'prolonged storm' for travel. Consequently, on May $5^{\text {th }}$, AirBnB announced that it was getting rid of one fourth of its workforce, which is about 1,900 employees. The Covid-19 pandemic meant that AirBnB had to review its marketing strategy or even reinvent its business model, that itself reinvented the accommodation marketplace in the first place.

1 AirBnB. https://news.airbnb.com/fast-facts/ 


\section{STARTING THE BUSINESS}

AirBnB's story began in 2007 when Brian Chesky and Joe Gebbia (see Appendix 1 for brief bio of co-founders), both graduates of the Rhode Island School of Design, having moved from New York to San Francisco, were unemployed and were having trouble paying their rent (see Appendix 2 for AirBnB's journey). It came to their attention that all the hotel rooms in the city were booked out due to a local Industrial Design conference. They saw the opportunity to make some money by renting out some of the space they had in their apartment. They bought some airbeds and quickly set up a simple web site called Air Bed \& Breakfast. Their first guests were a 30-year-old Indian man, a 35-year-old woman from Boston and a 45-year-old father of four from Utah. They charged each of them $\$ 80$ a night. Shortly after this beginning, Nathan Blecharczyk, a Harvard graduate and technical architect, joined the team as the third co-founder and Chief Technical Officer.

While the founders initially found it difficult to attract investors in their new venture, in 2009, they raised $\$ 20,000$ from their first investor, Y Combinator. They used this money to fly to New York City, their biggest market at the time, to meet users and promote the business. They found that a key problem was that the photos of the accommodations were not of good quality. They bought a high-quality camera and they visited each accommodation, taking new photographs for the web site. Returning to San Francisco with a more viable business model, they shortened the name to AirBnB.com and expanded their offering from just airbeds and shared accommodation, to a range of properties from entire homes and apartments to private rooms. By March 2009, the site had 10,000 users and 2,500 listings.

AirBnB's business model is referred to as a two-sided (more specifically, C2B2C) digital platform, matching the guests (travellers) with the hosts (property owners). In so doing, it creates value for both sides of the platform. Guests save money on the accommodation (compared to hotels), and hosts get earnings from their otherwise idle space. The company has a simple revenue model. There is no charge for the hosts to list their accommodation on the website. When guests book a property, AirBnB receives its revenue from two sources. Firstly, it charges a flat $10 \%$ commission from hosts for every booking made through the platform. Secondly, it charges $3 \%$ of the booking amount as a transaction fee from guests upon every confirmed booking.

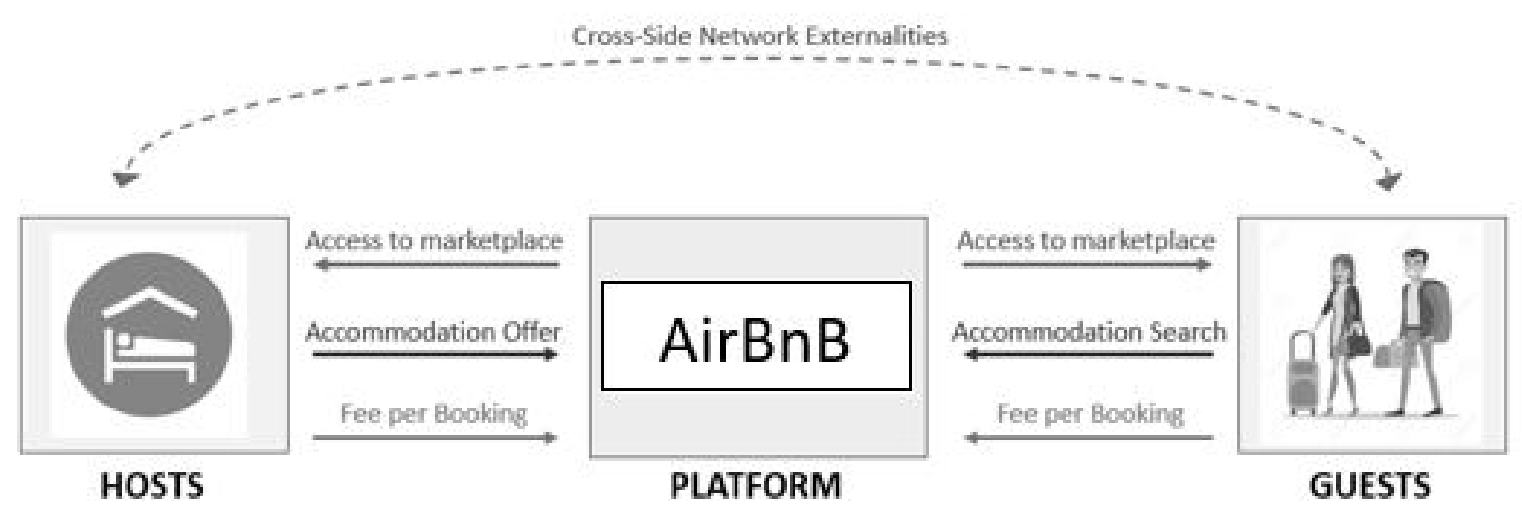

Figure 1: AirBnB as a two-sided platform

\section{BUSINESS EXPANSION}

In November 2010, AirBnB launched their iPhone app along with an Instant Book feature that enables bookings without the host's prior approval. The following year they opened an office in Germany, which marked the beginning of their international expansion. In May 2012, AirBnB introduced its $\$ 1 \mathrm{~m}$ Host Guarantee, which provided property damage protection of up to $\$ 1 \mathrm{~m}$ for every host at no extra cost. In 2014 , the company hosted more than 100,000 guests during the Rio World Cup and relaunched their brand. Over the following three years, AirBnB held open 
events in San Francisco, Paris and Los Angeles with the number of hosts attending growing from 1,500 to 7,000.

To add value to the customers, in 2016 AirBnB announced the launch of Trips ${ }^{2}$, which expanded its services beyond accommodation to local experiences recommended by hosts. With Trips, they also introduced a new identity authentication process that requires hosts and guests to provide an official government ID and a separate photograph that is matched to the authenticated ID. AirBnB notes that this more robust standard of authenticating identity made their community stronger and reaffirms their commitment to authenticity, reliability and security. In 2017, AirBnB expanded the Trips services to 20 more cities globally and launched its Chinese brand. The following year AirBnB introduced a new accommodation category AirBnB Plus, which recognises exceptionally high quality and comfort, at an extra charge of $\$ 149$ per host. In 2019, AirBnB signed an agreement to acquire HotelTonight ${ }^{3}$, an online app that allows users to find discounted last-minute hotel accommodation. This makes it easier for people who use AirBnB to find last-minute places to stay when Home hosts are often already booked. This, together with the Trips service, further expanded AirBnB's range of offerings for its customers. From its humble beginnings in 2007, AirBnB now connects travellers to more than 7 million places to stay and tens of thousands of experiences around the world. It is now the most searched for accommodations brand on Google.

To fund their expansion, AirBnB raised $\$ 4.7$ billion in total funding across 10 funding rounds (see Appendix 3 for more details on funding rounds). With the intention to undertake an initial public offering, the business was valued at $\$ 31$ billion at the beginning of the year 2020. In the last six years alone in its key US market, it has seen substantial gains in sales versus key industry competitors and similar gains in market share. Its yearly revenue has increased from $\$ 8.4$ billion in 2010 to $\$ 3.6$ billion in 2018 (see Appendix 4 for yearly figures). In 2018, its sales surpassed the Hilton group and it is also gaining on the Marriott hotel chain. On the $27^{\text {th }}$ March 2019 the company celebrated a key milestone, with the announcement that since its founding in 2007, half a billion guests had checked in at AirBnB listings worldwide ${ }^{4}$. In May 2019 the company announced that it had added 1 million new listings since July 2018, while in the same period Marriott had added 46,101 new rooms ${ }^{5}$. In August 2019 Reuters reported that AirBnB had recorded $\$ 9.4$ billion in total booking value in the first quarter, corresponding to a booking of 91 million nights on its platform in the same quarter 6 .

\section{BREACHES OF TRUST}

While in the initial years multiple bookings and stranded hosts were key issues, in recent years several cases are reported in which guests have discovered hidden cameras in their accommodation. One recent case occurred in Cork city in Ireland in April 20197. A family from New Zealand found a camera hidden in a smoke alarm in the living room. The father of the family, an IT consultant, discovered the camera after trying to connect his phone to the Wi$\mathrm{Fi}$. He found a link to a device which enabled him to watch a live video stream on his phone. The family's mother Ms. Barker said: 'We felt a sense of danger in the moment we discovered the camera. It felt like a huge invasion of our privacy and it felt like the exact opposite of what AirBnB should be about - mutual trust'. The family were very disappointed and upset with how AirBnB handled the investigation at the beginning. They felt they had to chase the company to get answers and even when the listing was removed from the platform they were not informed by AirBnB. The Cork city hidden camera incident is not an isolated incident. Similar cases are reported in Miami, Florida, California and Bulgaria, covered widely in the international press.

A spokesman for AirBnB responded in a press statement:

We have permanently removed this bad actor from our platform. Our original handling of this incident did not meet the high standards we set for ourselves, and we have apologized to the family and fully refunded their stay. The safety and privacy of our community - both online and offline - is our priority. AirBnB policies strictly prohibit hidden cameras in listings, and we take reports of any violations extremely seriously. There have been more than 500 million guest arrivals in AirBnB listings to date and negative incidents are incredibly rare.

\footnotetext{
2 AirBnB.https://news.airbnb.com/airbnb-expands-beyond-the-home-with-the-launch-of-trips/

3 AirBnB.https://news.airbnb.com/airbnb-signs-agreement-to-acquire-hoteltonight/

4 AirBnB.https://press.airbnb.com/airbnb-celebrates-half-a-billion-guest-arrivals/

5 AirBnB.https://press.airbnb.com/airbnbs-growth-and-summer-travel-updates/

6 Reuters (2019). Airbnb records 30\% growth rate in first-quarter on booking strength. Available at https://www.reuters.com/article/us-airbnb-results/

airbnb-records-30-growth-rate-in-first-quarter-on-booking-strength-source-idUSKCN1V700L

7 Irish Times (2019). Family 'felt sense of danger' after finding hidden live cam in Cork Airbnb. Available at https://www.irishtimes.com/news/consumer/ family-felt-sense-of-danger-after-finding-hidden-live-cam-in-cork-airbnb-1.3850498
} 


\section{ENSURING TRUST AND SAFETY}

AirBnB indeed realises trust and safety being central to their platform, as noted by Joe Gebbia in his 2016 TED talk. AirBnB has a 'Trust \& Safety' team which deals with traveling, hosting, community standards and home safety. In a study ${ }^{8}$ conducted jointly with Stanford University, it found that strong reputational mechanisms on the platform can overcome bias and can boost trust. It employs three reputational mechanisms to help its users overcome anxiety associated in dealing with strangers:

Profile - Guests and hosts on AirBnB need to create a profile for using the platform. A basic profile includes fields such as full name, phone number, payment information, and email address. The hosts also need to provide the photographs of the accommodation.

Secure messaging - The platform provides a secure messaging tool for communication between the guest and the host. The two parties may use the too for sharing additional information/requests, and for coordination.

Reviews - The reviews, in which the guests and hosts can review each other after the reservation, arguably provide the strongest reputational mechanism on the AirBnB. The Stanford study found that the rating system and textual reviews to be strong mechanism for maintaining trust.

To boost its trust ecosystem, AirBnB started a superhost programme in which exceptional hosts are eligible for a 'superhost' status based on the following criteria - average rating of 4.8 or above out of 5 , have completed at least 10 stays (or 100 nights over last 3 completed stays) over last year, less than $1 \%$ cancellation rate, and more than $90 \%$ response rate. Superhosts get benefit in the form of getting featured on the platform, attracting more hosts, and receiving additional bonus from the platform. There are around 400,000 superhosts on AirBnB platform, around ten percent of the overall hosts' number.

Moreover, to enhance the trust and safety on its platform, AirBnB provides the following features:

Account protection - AirBnB employs multi-factor authentication on its platform whenever there is an attempt to log-in from a new device or location. It also sends alerts whenever there is any change in the account or the transaction.

Scam prevention - AirBnB provides multilayer defence mechanisms against scams. This involves machine learning application to detect fake listings, removal of contact information until a booking is confirmed, and release of payments only after check-in. Thus, as long as the users stay on and communicate within the platform, they are protected from scams.

Secure payments - AirBnB transfer payments via its own platform and discourages users to pay via other means such as wired transfers / cash which are outside the platform. This helps in ensuring the traceability and security of the transactions.

Risk scoring - AirBnB scores each reservation for potential risk based on machine learning and predictive analytics. The scores are based on hundreds of flags based on past transactions.

Watchlists and background checks - AirBnB also regularly checks its hosts and guests against sanctions, regulatory, and terrorist watchlists. It also conducts its own background checks for its US customers.

Home preparedness - AirBnB runs home safety workshops with the hosts, in conjunction with local experts. The hosts are supposed to provide important local information to the guests. The company also provides free smoke and/or carbon monoxide detectors to the hosts if they wish so. In relation to the issue of hidden cameras, their policy ${ }^{9}$ for hosts clearly states: 'You should not spy on other people; cameras are not allowed in your listing unless they are previously disclosed and visible, and they are never permitted in private spaces (such as bathrooms or sleeping areas)'.

\section{FROM TWO-SIDED TO A MULTISIDED PLATFORM?}

With time AirBnB's trust and safety concerns have expanded beyond the two sides - hosts and guests - to the wider community. The concerns are mainly related to its legality in certain markets and the impact on the city life in general.

8 Abrahao, B., Parigi, P., Gupta, A., \& Cook, K. S. (2017). Reputation offsets trust judgments based on social biases among AirBnB users. Proceedings

of the National Academy of Sciences, 114(37), 9848-9853.

9 Source: AirBnB. https://www.airbnb.ie/help/article/887/what-are-airbnbs-rules-about-security-cameras-and-other-recording-devices-in-listings 
Consider the example of New York city. For short-term rentals (less than 30 days) in the city, the host must be present in the property, the rooms must be unlocked, and they cannot host more than two guests. While shortterm rentals are possible in small buildings (less than three residential units), larger buildings with three or more residential units must be rented at least for 30 days or more. Consequently, many listings on the platform were deemed illegal. To enforce the rules, city administration enacted a law in 2018, requiring such platforms to provide host's name and addresses to the authorities every month. In August 2018, AirBnB took the city administration into the court on the basis that this would breach the privacy of its hosts and endanger their freedom of activity. A federal court blocked the law in Jan 2019 terming it unconstitutional. Similar problems on the legality of AirBnB's listing exist across the globe, for instance in Barcelona, Berlin, Dublin, Paris, Perth or Tokyo. Furthermore, not all hosts are inclined to register their rentals with city authorities. For instance, it was reported ${ }^{10}$ in Feb 2020 that only around 250 property owners from Dublin city applied to register their short-term rentals with the council even though there were more than 7000 AirBnB properties listed in the area.

France is AirBnB's largest market outside the US, with around 65,000 homes in Paris listed at the time. A French tourism association complained in early 2019 to the European Union, noting that AirBnB was acting as a real estate agent and not complying with EU property rules, therefore representing unfair competition to the hotel industry. They argued that this represented a significant threat to existing hoteliers in the city. The matter was referred to the European Court of Justice, who issued an opinion in April 2019 stating that AirBnB should be treated as a digital service provider and free to operate across the European Union. The Court noted that AirBnB Ireland (from where AirBnB runs its French website) 'may be regarded as an information society service' and should benefit from the EU's free movement of information ${ }^{11}$.

Apart from legality, societal concerns are also coming to the fore ${ }^{12}$. For instance, the boom of AirBnB properties in Dublin and Lisbon is often blamed for the skyrocketing long-term rental market, fuelling the problem of homelessness in the city ${ }^{13}$. In cities like Barcelona or Florence, locals are complaining the 'touristification' of their city and the loss of community networks in a locality. In Athens, there have been complaints of too much noise from tourists' latenight parties and their mishandling of the rubbish. Thus, while the guest and hosts might rate each other high on the platform, AirBnB needs to generate trust with the local community.

The appointment of a Vice President of Trust in September 2019 was an attempt by the platform to ensure trust and safety among guests, hosts, and the community. The company notes that the Vice President of Trust is responsible for developing and implementing strategies that would make AirBnB as one of the most trusted online community in the world.

\section{AIRBNB IN A COVID-19 WORLD}

While the company has battled accusations that it drove up rents in many markets and contributed to the nation's housing-affordability crisis, the criticism and associated trust issues did not slow the company's explosive growth. It was something else that put a question mark on the future of the company. During the spring of 2020, the Covid-19 pandemic and subsequent travel restrictions caused serious threats to AirBnB.

In major markets of AirBnB, the effect of the Covid-19 pandemic really started taking place towards the end of February 2020. In the north of Italy, thousands of people were infected. Government agencies such as for the Centre for Disease Control in US and European Centre for Disease Prevention and Control recommended to avoid all nonessential international travel. As the pandemic spread to Spain, France, the UK, Ireland and the US, stricter confinement measures annihilated any tourism opportunities. By the end of April 2020, data from the United Nations World Tourism Organisation (UNWTO) shows that $100 \%$ of destinations now have restrictions in place.

AirBnB estimated that due to the Covid-19 pandemic, its revenue for the year 2020 is likely to be less than half of what it had in the previous year. According to AirDNA, an outside tracker of AirBnB listings, hosts saw $\$ 1.5$ billion in bookings dissipate for the month of March 2020 in the USA alone. By April 2020, AirBnB's valuation has plummeted

10 RTE (2020). Low compliance rate under laws restricting AirBnB lettings in Dublin city. Available at: https://www.rte.ie/news/dublin/2020/0219/1116267airbnb-dublin-lettings/

11 Lexology (2019). Regulatory Boost for Airbnb from ECJ's Advocate General. https://www.lexology.com/library/detail.aspx?g=fe934b09-9da5-41e3969d-df4f98545f55

12 FT (2019). Are AirBnB investors destroying Europe's cultural capitals? https://www.ft.com/content/2fe06a7c-cb2a-11e9-af46-b09e8bfe60c0

13 Guardian (2018). 30,000 empty homes and nowhere to live: inside Dublin's housing crisis. https://www.theguardian.com/cities/2018/nov/29/empty-

dublin-housing-crisis-airbnb-homelessness-landlords 
from $\$ 31$ billion at its 2017 fundraising to $\$ 18$ billion. The company, which was initially due to go public in 2020 , announced ${ }^{14}$ on May $5^{\text {th }} 2020$ that it will slash one fourth of its workforce - around 1,900 people.

The pandemic represents an immense challenge to the travel industry. It is likely to substantially change our travel habits but perhaps more fundamentally where we live and how we work. All these changes represent some challenges yet some opportunities for AirBnB.

A report by Bain Group notes how distance is one of the most fundamental economic factors in today's economy ${ }^{15}$. Traditionally, cities were considered a cornerstone of spatial economics - highly dense urban hubs minimising the cost of moving raw materials, labour and finished goods. However, thanks to technology, the "cost of distance' is declining in the recent times. For instance, big, energy consuming data centres are usually hosted far from the cities. Such trends are likely to accelerate as a result of the coronavirus crisis. If proximity to one's job location is no longer a significant factor in deciding where to live, then the appeal of the suburbs wanes; and remote but digitally connected villages become extremely attractive. AirBnB which is in the business of leveraging on idle capacity could possibly benefit from this trend. This would however require the company to revise its current approach. The big question is how?

Travel habits are also likely to be affected. Using the hashtag \#traveltomorrow, United Nations specialized agency for tourism (UNWTO) invites people to travel differently in the future. It believes that people may travel to learn from different cultures and to return home enriched and to advance development and promote sustainability. Similarly, it is reported that tourists may not travel as far as they used to and start (re)discovering the world around them instead of far away. Could those concerns and opportunity be integrated by AirBnB in its attempt to build trust with various stakeholders?

Less than 13 years after its inception, AirBnB which had been a major disruptor in the travel industry is now being disrupted. The company needs to think of solutions to sustain its business model and take an active part in the shaping of a better world post-Covid-19.

\section{QUESTIONS}

1. How does AirBnB create value? What is (are) the value proposition(s) of AirBnB? How does it differ from other traditional businesses?

2. Explain the importance of reputational mechanisms in maintaining trust in the context of online $\mathrm{C} 2 \mathrm{~B} 2 \mathrm{C}$ markets. Explain how AirBnB uses reputational mechanisms to ensure and enhance trust between the two sides of the platform.

3. How can AirBnB maintain a sustainable tourism platform reputation and address the concerns over its alleged negative impact discussed in the case?

4. What are the possible behavioural changes of business and personal travellers' resulting from the covid-19 pandemic? How can Airbnb respond to those long-term changes? Should it be reconsidering its target audience? Its value proposition? Its business model? How?

14 Forbes (2020). Airbnb Lays Off 25\% Of Its Employees: CEO Brian Chesky Gives A Master Class In Empathy And Compassion. https://www.forbes.com/ sites/jackkelly/2020/05/06/airbnb-lays-off-25-of-its-employees-ceo-brian-chesky-gives-a-master-class-in-empathy-and-compassion/\#58b548cdee30 15 Bain \& Company (2016). Spatial Economics: The Declining Cost of Distance. https://www.bain.com/insights/spatial-economics-the-declining-cost-ofdistance/ 


\section{APPENDIX 1 - FOUNDERS PROFILES ${ }^{16}$}

\section{Brian Chesky, Co-founder, CE0, Head of Community}

Brian Chesky is the co-founder, Head of Community, and CEO of AirBnB, which he started with Joe Gebbia and Nathan Blecharczyk in 2008. Originally from New York, Brian graduated from the Rhode Island School of Design where he received a Bachelor of Fine Arts in Industrial Design. Brian sets the company's strategy to connect people to unique travel experiences and drives AirBnB's mission to create a world where anyone can belong anywhere.

\section{Joe Gebbia, Co-Founder \& CPO}

Joe Gebbia is the co-founder and CPO of AirBnB, serving on the Board of Directors and Executive staff, while leading Samara, AirBnB's in-house design and innovation studio. Like Brian, he is also an alumnus of the Rhode Island School of Design, where he earned dual degrees in Graphic Design and Industrial Design. An entrepreneur from an early age, AirBnB's ground-breaking service began in his San Francisco apartment. He is involved in crafting the company culture, shaping the design aesthetic, and innovating future growth opportunities. Joe has spoken globally about both entrepreneurship and design and received numerous distinctions such as the Inc. 30 under 30 and Fortune 40 under 40. Gebbia now serves on the institution's Board of Trustees.

\section{Nathan Blecharczyk, Co-Founder, CSO, Chairman of AirBnB China}

Nathan Blecharczyk is the co-founder, Chief Strategy Officer, and Chairman of AirBnB China. Nathan became an entrepreneur in his youth, running a business while he was in high school that sold to clients in more than 20 countries. He earned a degree in Computer Science from Harvard University and held several engineering positions before co-founding AirBnB. Nathan plays a leading role in driving key strategic initiatives across the global business. Previously he oversaw the creation of AirBnB's engineering, data science, and performance marketing teams. 


\section{APPENDIX 2 - AIRBNB'S DEVELOPMENT STORY}

$\begin{aligned} & \text { Brian Chesky and Joe Gebbia use air-beds to } \\ & \text { make rent money when hotels are sold out }\end{aligned}$
$\begin{aligned} & \text { Name changed to Airbnb; Expands beyond } \\ & \text { rooms to include apartments and houses }\end{aligned}$
$\begin{aligned} & \text { International expansion begins with German } \\ & \text { office }\end{aligned}$

Figure 2: AirBnB's development story (Data Source: https://news.airbnb.com/fast-facts/)

\section{APPENDIX 3 - AIRBNB FUNDING ROUNDS}

Table 1: AirBnB Funding Rounds (Data Source: https://craft.co/airbnb/funding-rounds)

\begin{tabular}{|c|c|c|c|}
\hline Funding Type & Date & Amount Raised & Post-money Valuation \\
\hline Seed & Jan 2009 & $\$ 20 k$ & $\$ 2.5 \mathrm{~m}$ \\
\hline Seed & Apr 2009 & $\$ 615 k$ & \\
\hline Series A & Nov 2010 & $\$ 7.2 \mathrm{~m}$ & $\$ 70 m$ \\
\hline Series B-1 & Jul 2011 & $\$ 114.9 \mathrm{~m}$ & $\$ 1.3 b$ \\
\hline Series B-2 & Jul 2011 & $\$ 2.1 \mathrm{~m}$ & \\
\hline Series C & Oct 2013 & $\$ 200 \mathrm{~m}$ & $\$ 2.9 \mathrm{~b}$ \\
\hline Series D & Apr 2014 & $\$ 519.7 \mathrm{~m}$ & $\$ 10.5$ b \\
\hline Series E-1 & Jun 2015 & $\$ 1.6 b$ & $\$ 25.5$ b \\
\hline Series E-2 & Nov 2015 & $\$ 100 \mathrm{~m}$ & \\
\hline Debt & Jul 2016 & $\$ 1 \mathrm{~b}$ & \\
\hline Series $F$ & Sept 2016 & $\$ 1 \mathrm{~b}$ & $\$ 31 \mathrm{~b}$ \\
\hline Unattributed & Apr 2019 & $\$ 201.6 \mathrm{~m}$ & \\
\hline Unattributed & Aug 2019 & $\$ 25.9 \mathrm{~m}$ & \\
\hline
\end{tabular}




\section{APPENDIX 4 - AIRBNB REVENUE OVER THE YEARS}

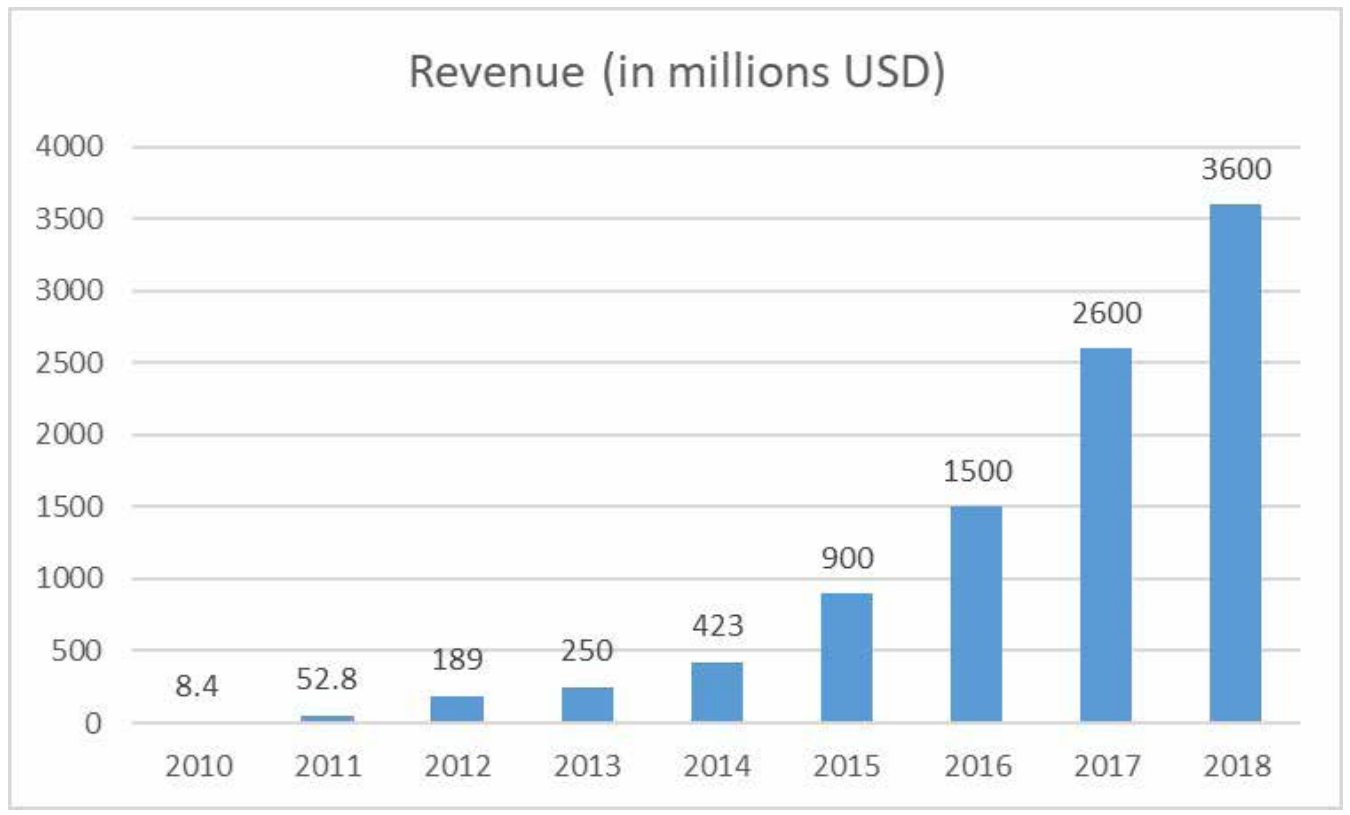

Figure 3: AirBnB revenue over the years (Data Source: https://craft.co/airbnb/metrics) 